Article

\title{
Constituents of the Fruits of Citrus medica L. var. sarcodactylis and the Effect of 6,7-Dimethoxy-coumarin on Superoxide Anion Formation and Elastase Release
}

\author{
Yu-Yi Chan ${ }^{1}$, Tsong-Long Hwang ${ }^{2,3,4}$, Ping-Chung Kuo ${ }^{5}$, Hsin-Yi Hung ${ }^{5}$ \\ and Tian-Shung $\mathrm{Wu}^{5,6, *}$ \\ 1 Department of Biotechnology, Southern Taiwan University of Science and Technology, Tainan 71005, Taiwan; \\ yuyichan@stust.edu.tw \\ 2 Graduate Institute of Natural Products, College of Medicine, Chang Gung University, Taoyuan 333, Taiwan; \\ htl@mail.cgu.edu.tw \\ 3 Research Center for Chinese Herbal Medicine, Research Center for Food and Cosmetic Safety, \\ and Graduate Institute of Health Industry Technology, College of Human Ecology, \\ Chang Gung University of Science and Technology, Taoyuan 333, Taiwan \\ 4 Department of Anesthesiology, Chang Gung Memorial Hospital, Taoyuan 333, Taiwan \\ 5 School of Pharmacy, College of Medicine, National Cheng Kung University, Tainan 701, Taiwan; \\ z10502016@email.ncku.edu.tw (P.-C.K.); z10308005@email.ncku.edu.tw (H.-Y.H.) \\ 6 Department of Pharmacy, College of Pharmacy and Health Care, Tajen University, Pingtung 907, Taiwan \\ * Correspondence: tswu@mail.ncku.edu.tw; Tel.: +886-6-2747538.
}

Received: 3 August 2017; Accepted: 30 August 2017; Published: 1 September 2017

\begin{abstract}
Investigation of the chemical constituents from the fruits of Citrus medica L. var. sarcodactylis Swingle has led to the characterization of a new sesquiterpene 1 along with thirty-two known compounds. The structure of $\mathbf{1}$ was established on the basis of 2D NMR spectroscopic and mass spectrometric analyses, and the known compounds were identified by comparison of their physical and spectroscopic data with those reported in the literature. In addition, most of the isolated compounds were evaluated for the activity assayed by the in vitro inhibition of superoxide anion generation and elastase release by human neutrophils. The results showed that only 6,7-dimethoxycoumarin (5) exhibited significant inhibition of superoxide anion generation, with $\mathrm{IC}_{50}$ value of $3.8 \pm 1.4 \mu \mathrm{M}$.
\end{abstract}

Keywords: Citrus medica L. var. sarcodactylis Swingle; Rutaceae; sesquiterpene; citrumedin-C; superoxide anion formation; elastase release

\section{Introduction}

Citrus medica L. var. sarcodactylis Swingle belongs to the genus Citrus (Rutaceae), and is commonly distributed in South and Southeast Asia. The plant is cultivated in the tropics and sub-tropics, such as India, Sri Lanka, Thailand, Vietnam, China, Japan, and Taiwan. Various species of Citrus have been used as foods, and their fruits, leaves, and roots have also been used as folk medicine or spice in Taiwan [1]. Citrus is one genus of the economically and medicinally important Rutaceae family, which has shown extensive biological and pharmacological activities, including antitumor [2-7], antiallergic [8], antioxidant [9-12], antiplatelet aggregation [13], anti-microbial [14-17], and anti-inflammatory activity [18-22]. Moreover, Citrus species have been reported to contain various bioactive coumarins, flavonoids, tetranortriterpenoids, monoterpenoids, and acridone alkaloids [23-34]. Previously, several anti-inflammatory compounds have been isolated from the stems and root barks of the titled plant [18]. 
In order to investigate the bioactive constituents from different parts of $C$. medica var. sarcodactylis, the fruits of this plant were selected for investigation. As a result, a new sesquiterpene $\mathbf{1}$ (Figure 1) and thirty-two known compounds have been characterized in the present work. The structural elucidation of $\mathbf{1}$ is described herein.
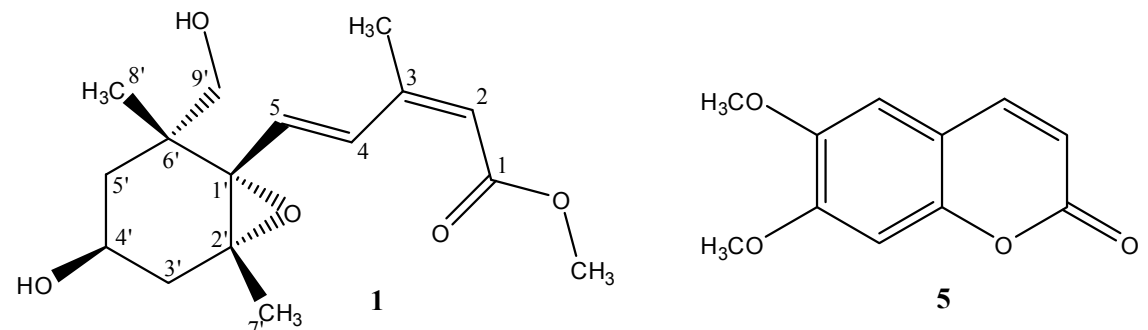

Figure 1. Structures of compounds 1 (relative configuration) and 5.

\section{Results and Discussion}

\subsection{Purification and Characterization}

The fresh fruits of $C$. medica var. sarcodactylis were pulverized into powder and extracted five times with methanol under reflux, and the combined extracts were concentrated to give a deep brown syrup. The crude extract was suspended in water and partitioned with $\mathrm{CHCl}_{3}$ to afford $\mathrm{CHCl}_{3}$ layer and water-soluble layer, respectively. Each layer was subjected to purification by a combination of conventional chromatographic techniques to result in one new compound (1). In addition, thirty-two known compounds were identified to be 5,7-dimethoxycoumarin (2) [3], xanthyletin (3) [18], oxypeucedanin hydrate (4) [35], 6,7-dimethoxycoumarin (5) [18], skimmin (6) [36], haploperoside A (7) [37], leptodactylone (8) [18], 7-methoxycoumarin (9) [18], scopoletin (10) [36], cis-head-to-tail-limittin dimer (11) [38], umbelliferone (12) [36], nordentatin (13) [18], limonin (14) [18], nomilin (15) [18], citrusin (16) [3], obacunone (17) [39], 3-(2-O- $\beta$-D-glucopyranosyl-4-methoxyphenyl)-propanoic acid (18) [40], cis-p-coumaric acid (19) [18], methyl vanillate (20) [41], methyl benzoate (21) [42], methyl paraben (22) [43], 4-hydroxy-phenethyl alcohol (23) [44], methyl-4-hydroxycinnamate (24) [43], coniferin (25) [45], syringin (26) [45], (E)-6-hydroxy-2,6-dimethylocta-2,7-dienoic acid (27) [46], a mixture of stigmasterol (28) [3] and $\beta$-sitosterol (29) [3], $\beta$-sitosteryl glucoside (30) [47], chrysoeriol 8-C-glucoside (31) [48], 1,2,3,4-tetrahydro- $\beta$-carboline-3-carboxylic acid (32) [49], and citrylidene malonic acid (33) [50], respectively. The structures of these compounds were identified by comparison of their physical and spectroscopic data with the values reported in the literature.

\subsection{Structural Elucidation of Compound $\mathbf{1}$}

Citrumedin-C (1) was isolated as an optically active colorless powder. The HR-EI-MS analysis of 1 showed a molecular ion peak $\left([\mathrm{M}]^{+}\right)$at $m / z 296.1623$, which was in agreement with the molecular formula $\mathrm{C}_{16} \mathrm{H}_{24} \mathrm{O}_{5}$. The UV spectrum appeared to show the maximum absorption at $266 \mathrm{~nm}$. The IR spectrum revealed the presence of hydroxyl $\left(3399 \mathrm{~cm}^{-1}\right)$ and carbonyl groups $\left(1701 \mathrm{~cm}^{-1}\right)$. The ${ }^{1} \mathrm{H}-\mathrm{NMR}$ spectrum of 1 exhibited signals for one vinyl proton at $\delta 5.79(1 \mathrm{H}, \mathrm{s})$, two trans olefinic protons at $\delta 8.00(1 \mathrm{H}, \mathrm{d}, J=15.7 \mathrm{~Hz})$ and $6.55(1 \mathrm{H}, \mathrm{d}, J=15.7 \mathrm{~Hz})$, two methyl singlets at $\delta 1.16(3 \mathrm{H})$ and $0.94(3 \mathrm{H})$, one methyl group attached to a double bond at $\delta 2.10(3 \mathrm{H}, \mathrm{s})$, one methoxy group at $\delta$ $3.70(3 \mathrm{H}, \mathrm{s})$, one oxymethine at $\delta 4.12(1 \mathrm{H}, \mathrm{m})$, two oxymethylene protons at $\delta 3.82(1 \mathrm{H}, \mathrm{d}, J=7.5 \mathrm{~Hz})$ and $3.72(1 \mathrm{H}, \mathrm{d}, J=7.5 \mathrm{~Hz})$, one geminally coupled methylene at $\delta 2.03(1 \mathrm{H}, \mathrm{dd}, J=13.7,7.0 \mathrm{~Hz})$ and $1.73(1 \mathrm{H}, \mathrm{dd}, J=13.7,10.4 \mathrm{~Hz})$, and one methylene group attached with a methine at $\delta 1.86(1 \mathrm{H}, \mathrm{dd}$, $J=13.5,6.9 \mathrm{~Hz})$ and $1.68(1 \mathrm{H}, \mathrm{dd}, J=13.5,13.5 \mathrm{~Hz})$, respectively. The ${ }^{13} \mathrm{C}-\mathrm{NMR}$ spectrum exhibited a carbonyl signal at $\delta 168.2$ (s); four olefinic carbons at $\delta 152.0$ (s), 135.7 (d), 131.7 (d), and 118.3 (d); and two oxygenated carbons at $\delta 87.8$ (s) and $\delta 83.3$ (s) (Table 1), and these results were confirmed by 
the HSQC analysis. The COSY correlations of $\mathrm{H}-4^{\prime}(\delta 4.12)$ to $\mathrm{H}-3^{\prime}(\delta 2.03$ and 1.73$)$ and $\mathrm{H}-5^{\prime}(\delta 1.86$ and 1.68) suggested the presence of the partial structure $\left(-\mathrm{CH}_{2}-\mathrm{CH}(-\mathrm{O}-)-\mathrm{CH}_{2}-\right)$. The six-membered C-ring was established by the HMBC correlations from $\mathrm{H}-5^{\prime}(\delta 1.86)$ to $\mathrm{C}-6^{\prime}(\delta 49.2)$ and $\mathrm{C}-1^{\prime}(\delta 83.3)$, and from $\mathrm{H}-3^{\prime}(\delta 2.03)$ to $\mathrm{C}-2^{\prime}(\delta 87.8)$ and $\mathrm{C}-1^{\prime}(\delta 83.3)$ (Table 1, Figure 2$)$. The HMBC spectrum of 1 also showed the conjugated crosspeaks of $\mathrm{H}-5(\delta 6.55)$ to $\mathrm{C}-3(\delta 152.0) / \mathrm{C}-1^{\prime}(\delta 83.3), \mathrm{CH}_{3}-3(\delta 2.10)$ to $\mathrm{C}-2(\delta 118.3) / \mathrm{C}-3(\delta 152.0) / \mathrm{C}-4(\delta 131.7)$, and $\mathrm{OCH}_{3}(\delta 3.70)$ to $\mathrm{C}-1$ ( $\left.\delta 168.2\right)$, indicating that the partial structure $\left(-\mathrm{CH}=\mathrm{CH}-\mathrm{C}\left(-\mathrm{CH}_{3}\right)=\mathrm{CH}-\mathrm{C}(=\mathrm{O})-\mathrm{O}-\mathrm{CH}_{3}\right)$ was substituted at $\mathrm{C}-1^{\prime}$. The HMBC correlations

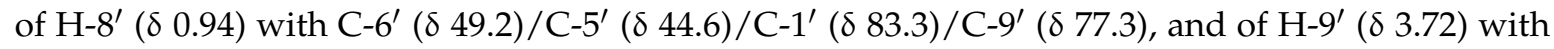
$\mathrm{C}-5^{\prime}(\delta 44.6) / \mathrm{C}-1^{\prime}(\delta 83.3)$ revealed that the quaternary C- $6^{\prime}$ was substituted with both methyl and hydroxymethyl groups. In addition, the correlations of the oxygenated quaternary carbon C-2' $(\delta 87.8)$ and $C-1^{\prime}(\delta 83.3)$ with $\mathrm{H}^{-7^{\prime}}(\delta 1.16)$ supported that the $\mathrm{C}-2^{\prime}$ was substituted with a methyl group. According to the chemical shifts and the degree of unsaturation, it also suggested the presence of an epoxide ring at $\mathrm{C}-1^{\prime}$ and $\mathrm{C}-2^{\prime}$, and a hydroxyl group connected at $\mathrm{C}-4^{\prime}$, and these were further confirmed with the 2D spectroscopic analytical data. Thus, the structure of $\mathbf{1}$ was similar to abscisic acid (ABA) and xanthoxin in the phytohormone, which played the key role in biotic and abiotic stress responses [51]. The relative stereochemistry was confirmed by a NOESY experiment, which showed correlations of $\mathrm{CH}_{3}-8^{\prime} / \mathrm{CH}_{3}-7^{\prime}, \mathrm{H}-4^{\prime} / \mathrm{H}-9^{\prime}, \mathrm{H}-3^{\prime}$ ( $\left.\delta 1.73\right) / \mathrm{H}-5$, and $\mathrm{H}-3^{\prime}$ ( $\left.\delta 1.73\right) / \mathrm{CH}_{3}-7^{\prime}$, respectively (Figure 3). Therefore, the side chain at $\mathrm{C}-1^{\prime}$, two methyl substituents at $\mathrm{C}-2^{\prime}$ and $\mathrm{C}-6^{\prime}$, and the hydroxyl group at $C-4^{\prime}$ were all in cis configuration. Conclusively, the structure of citrumedin-C (1) was assigned as shown based on the above-mentioned observations (See Supplementary Materials).

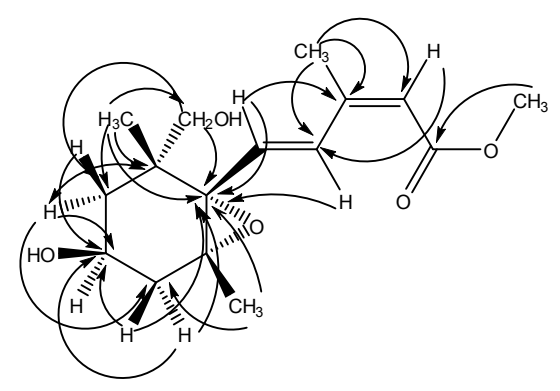

Figure 2. HMBC Correlations of $\mathbf{1 .}$

Table 1. ${ }^{1} \mathrm{H}$ - and ${ }^{13} \mathrm{C}-\mathrm{NMR}$ spectral data of $\mathbf{1}\left(\mathrm{CD}_{3} \mathrm{OD}, 400 \mathrm{MHz}\right)$.

\begin{tabular}{lll}
\hline Position & $\boldsymbol{\delta}_{\mathbf{H}}$ (mult., J in Hz) & $\boldsymbol{\delta}_{\mathbf{C}}$ \\
\hline 1 & & 168.2 \\
2 & $5.79(1 \mathrm{H}, \mathrm{s})$ & 118.3 \\
3 & & 152.0 \\
4 & $8.00(1 \mathrm{H}, \mathrm{d}, 15.7)$ & 131.7 \\
5 & $6.55(1 \mathrm{H}, \mathrm{d}, 15.7)$ & 135.7 \\
$1^{\prime}$ & & 83.3 \\
$2^{\prime}$ & & 87.8 \\
$3^{\prime}$ & $2.03(1 \mathrm{H}, \mathrm{dd}, 13.7,7.0)$ & 46.0 \\
$4^{\prime}$ & $1.73(1 \mathrm{H}, \mathrm{dd}, 13.7,10.4)$ & 66.0 \\
$5^{\prime}$ & $4.12(1 \mathrm{H}, \mathrm{m})$ & 44.6 \\
$6^{\prime}$ & $1.86(1 \mathrm{H}, \mathrm{dd}, 13.5,6.9)$ & 49.2 \\
$7^{\prime}$ & $1.68(1 \mathrm{H}, \mathrm{dd}, 13.5,13.5)$ & 19.6 \\
$8^{\prime}$ & $1.16(3 \mathrm{H}, \mathrm{s})$ & 16.4 \\
$9^{\prime}$ & $0.94(3 \mathrm{H}, \mathrm{s})$ & 77.3 \\
$\mathrm{CH}_{3}-3$ & $3.82(1 \mathrm{H}, \mathrm{d}, 7.5)$ & 21.2 \\
$\mathrm{OCH}_{3}$ & $3.72(1 \mathrm{H}, \mathrm{d}, 7.5)$ & 51.6 \\
\hline
\end{tabular}




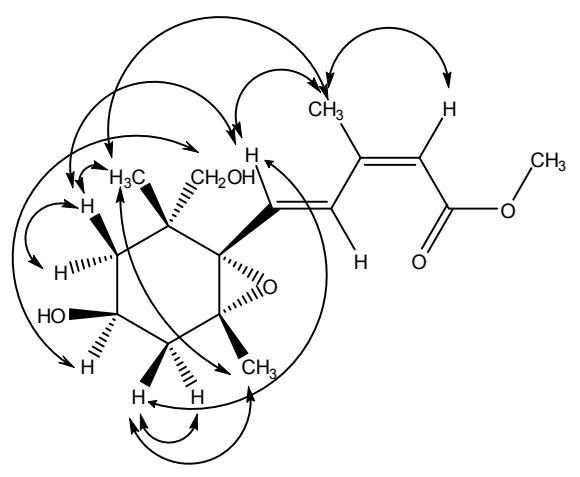

Figure 3. NOESY Correlations of $\mathbf{1 .}$

\subsection{The Inhibitory Activity of Superoxide Anion Generation and Elastase Release}

Most of the isolated compounds (compounds 2-6, 10, 12, 14-18, and 31) were examined for their inhibition of superoxide anion generation and elastase release by human neutrophils in response to $\mathrm{N}$-formyl-L-methionyl-phenylalanine/cytochalasin B (fMLP/CB) [52,53]. Only compound 5 (Figure 1) displayed inhibition percentages greater than $50 \%$ at the test concentration of $10 \mu \mathrm{M}$, and in the concentration range used, this compound displayed inhibitory effects in a dose-dependent manner. Compound 5 displayed significant inhibition of superoxide anion generation with $\mathrm{IC}_{50}$ value of $3.8 \pm 1.4 \mu \mathrm{M}$, compared to the reference compound LY294002 with $\mathrm{IC}_{50}$ values of $0.4 \pm 0.02 \mu \mathrm{M}$ [52] (Table 2).

Table 2. Inhibitory effects of isolated compounds on superoxide anion generation and elastase release by human neutrophils in response to $N$-formyl-L-methionyl-phenylalanine/cytochalasin B (fMLP/CB).

\begin{tabular}{lll}
\hline \multirow{2}{*}{ Compound } & \multicolumn{2}{c}{$\mathrm{IC}_{50}(\mu \mathrm{M})^{\mathrm{a}}$} \\
\cline { 2 - 3 } & Superoxide Anion Generation & Elastase Release \\
\hline 5 & $3.8 \pm 1.4^{* * *}$ & $>10$ \\
$\mathrm{LY}^{*} 24002^{\mathrm{b}}$ & $0.4 \pm 0.02^{* * *}$ & $1.5 \pm 0.3^{* * *}$ \\
\hline
\end{tabular}

${ }^{a}$ Concentration necessary for $50 \%$ inhibition $\left(\mathrm{IC}_{50}\right)$. Results are presented as means $\pm \mathrm{SD}(n=3-4)$. ${ }^{* * *} p<0.001$ compared with the control (DMSO). ${ }^{\mathrm{b}}$ A phosphatidylinositol-3-kinase inhibitor was used as a positive control.

\section{Materials and Methods}

\subsection{General Information}

Melting points were determined using an MP-S3 apparatus (Yanaco, Tokyo, Japan). Optical rotations were measured using a P-2000 digital polarimeter (JASCO, Tokyo, Japan). UV spectra were recorded at room temperature on a U-0080-D spectrophotometer (Hitachi, Tokyo, Japan). IR spectra were obtained with an FT-IR Spectrum RX I spectrophotometer (PerkinElmer, Waltham, MA, USA). The EI-MS and HR-EI-MS were obtained on a VG-70-250S mass spectrometer. The ${ }^{1} \mathrm{H}-$ and ${ }^{13} \mathrm{C}$-NMR, DEPT, COSY, HMQC, NOESY, and HMBC experiments were recorded on a Bruker AMX-400 spectrometer. Standard pulse sequences and parameters were used for the NMR experiments, and all chemical shifts were reported in parts per million (ppm, $\delta$ ). Column chromatography (CC) was performed on silica gel (70-230 mesh and 230-400 mesh, Merck, Darmstadt, Germany), Diaion HP-20 (Mitsubishi, Tokyo, Japan), and C 18 (Sigma-Aldrich, St. Louis, MO, USA) gels, respectively, and preparative TLC (thin-layer chromatography) was conducted on Merck precoated silica gel 60 F254 plates, using UV light to visualize the spots. All solvents of extraction and isolation were purchased from Merck (Darmstadt, Germany). 


\subsection{Materials}

The fruits of Citrus medica L. var. sarcodactylis Swingle was collected from the markets of Hualien County, Taiwan in September 2002, and identified by Prof. Chang-Sheng Kuoh. A voucher specimen (TSWu 20020923) has been deposited in the Herbarium of National Cheng Kung University, Tainan, Taiwan.

\subsection{Extraction and Isolation}

The fresh whole fruits of Citrus medica L. var. sarcodactylis Swingle $(7.97 \mathrm{~kg})$ were pulverized into small pieces and extracted with methanol under reflux $(40 \mathrm{~L} \times 5 \mathrm{~h} \times 5)$. The resulting solution was then filtered and concentrated in vacuo to yield a crude extract. The $\mathrm{MeOH}$ extract (696 g) was suspended in distilled water and successively partitioned with chloroform yielding a chloroform layer (26 g) and water-soluble layer (670 g). The chloroform layer $(26 \mathrm{~g})$ was chromatographed directly on silica gel and eluted with a gradient of $n$-hexane and ethyl acetate to afford eight fractions. Fraction 3 was rechromatographed on silica gel and eluted with solvent of $n$-hexane-acetone $(25: 1)$ to give a mixture of $\beta$-sitosterol (28) and stigmasterol $\left(\mathbf{2 9}, 227 \mathrm{mg}, \mathrm{R}_{\mathrm{f}}=0.6\right)$, and citrylidene malonic acid (33, $1 \mathrm{mg}$, $\mathrm{R}_{\mathrm{f}}=0.4$ ). Purification of fraction 4 by column chromatography with silica gel was eluted by gradient solvent mixture of chloroform and ethyl acetate (20:1 to 1:1) to afford 7-methoxycoumarin (9,5 mg, $\left.\mathrm{R}_{\mathrm{f}}=0.8\right)$, nordentatin $\left(\mathbf{1 3}, 1 \mathrm{mg}, \mathrm{R}_{\mathrm{f}}=0.7\right)$, nomilin $\left(\mathbf{1 5}, 19 \mathrm{mg}, \mathrm{R}_{\mathrm{f}}=0.6\right)$, methyl vanillate $(\mathbf{2 0}, 1 \mathrm{mg}$, $\left.\mathrm{R}_{\mathrm{f}}=0.5\right)$, 4-hydroxy-phenethyl alcohol (23,1 mg, $\left.\mathrm{R}_{\mathrm{f}}=0.3\right)$, and methyl-4-hydroxycinnamate (24, $2 \mathrm{mg}$, $R_{\mathrm{f}}=0.2$ ), respectively. Separation of fraction 5 by column chromatography with silica gel eluted by chloroform and methanol (20:1) solvent mixture yielded xanthyletin $\left(3,13 \mathrm{mg}, \mathrm{R}_{\mathrm{f}}=0.7\right)$, leptodactylone $\left(\mathbf{8}, 1 \mathrm{mg}, \mathrm{R}_{\mathrm{f}}=0.5\right)$, umbelliferone $\left(\mathbf{1 2}, 11 \mathrm{mg}, \mathrm{R}_{\mathrm{f}}=0.4\right)$, and methyl paraben $\left(\mathbf{2 2}, 1 \mathrm{mg}, \mathrm{R}_{\mathrm{f}}=0.3\right)$. Fraction 6 was purified by silica gel CC eluted by a gradient solvent mixture of chloroform and methanol (20:1 to 1:1) to afford 5,7-dimethoxycoumarin (2, $\left.198 \mathrm{mg}, \mathrm{R}_{\mathrm{f}}=0.6\right), 6,7$-dimethoxycoumarin $(5,24 \mathrm{mg}$, $\left.\mathrm{R}_{\mathrm{f}}=0.6\right)$, scopoletin $\left(\mathbf{1 0}, 21 \mathrm{mg}, \mathrm{R}_{\mathrm{f}}=0.5\right)$, cis-head-to-tail-limittin dimer $\left(\mathbf{1 1}, 1 \mathrm{mg}, \mathrm{R}_{\mathrm{f}}=0.3\right)$, and limonin $\left(\mathbf{1 4}, 59 \mathrm{mg}, \mathrm{R}_{\mathrm{f}}=0.2\right)$. Fraction 7 underwent a series of chromatographic separations on silica gel using chloroform/ methanol (15:1) as eluent to afford oxypeucedanin hydrate $\left(4,12 \mathrm{mg}, \mathrm{R}_{\mathrm{f}}=0.8\right)$, citrusin $\left(\mathbf{1 6}, 15 \mathrm{mg}, \mathrm{R}_{\mathrm{f}}=0.6\right)$, obacunone $\left(\mathbf{1 7}, 16 \mathrm{mg}, \mathrm{R}_{\mathrm{f}}=0.5\right)$, and (E)-6-hydroxy-2,6-dimethylocta-2,7-dienoic acid $\left(27,1 \mathrm{mg}, \mathrm{R}_{\mathrm{f}}=0.3\right)$. Recrystallization of fraction 8 produced the solid $\beta$-sitosteryl glucoside $(30,23 \mathrm{mg})$.

The water layer was subjected directly to Diaion HP-20 column chromatography, eluted by water and gradient with methanol to give six fractions. Fraction 4 was chromatographed over Sephadex LH-20 eluted with gradient solvent mixture of water and methanol to give skimmin (6, $\left.17 \mathrm{mg}, \mathrm{R}_{\mathrm{f}}=0.7\right)$, haploperoside A (7, $\left.1 \mathrm{mg}, \mathrm{R}_{\mathrm{f}}=0.6\right)$, methyl benzoate $\left(\mathbf{2 1}, 1 \mathrm{mg}, \mathrm{R}_{\mathrm{f}}=0.5\right)$, coniferin $\left(25,27 \mathrm{mg}, \mathrm{R}_{\mathrm{f}}=0.3\right)$, and syringin $\left(\mathbf{2 6}, 7 \mathrm{mg}, \mathrm{R}_{\mathrm{f}}=0.2\right)$. Fraction 5 was chromatographed on silica gel and eluted with solvent mixture of chloroform and methanol (5:1) to afford 3-(2-O- $\beta$ D-glucopyranosyl-4-methoxyphenyl)propanoic acid (18, $\left.11 \mathrm{mg}, \mathrm{R}_{\mathrm{f}}=0.5\right)$ and 1,2,3,4-tetrahydro- $\beta$ carboline-3- carboxylic acid $\left(32,3 \mathrm{mg}, \mathrm{R}_{\mathrm{f}}=0.3\right)$. Fraction 6 was rechromatographed on silica gel and eluted with mixture of chloroform and methanol (9:1) to give citrumedin-C (1, $\left.1 \mathrm{mg}, \mathrm{R}_{\mathrm{f}}=0.7\right)$, cis-p-coumaric acid $\left(\mathbf{1 9}, 1 \mathrm{mg}, \mathrm{R}_{\mathrm{f}}=0.6\right)$, and chrysoeriol 8-C-glucoside $\left(\mathbf{3 1}, 8 \mathrm{mg}, \mathrm{R}_{\mathrm{f}}=0.2\right)$.

Citrumedin-C (1): colorless powder, mp 138-139 ${ }^{\circ} \mathrm{C} ;[\alpha]_{\mathrm{D}}+50.5\left(\mathrm{CHCl}_{3}, c=0.07\right) ; \mathrm{UV} \lambda_{\max }(\mathrm{MeOH})$ $\mathrm{nm}(\log \varepsilon) 266$ (4.38); IR(KBr) $\nu_{\max } \mathrm{cm}^{-1} 3399,2920,2874,1701,1601,1447,1373,1234,1165 ;{ }^{1} \mathrm{H}-$ and ${ }^{13}$ C-NMR data, see Table 1. EI-MS m/z 296 ([M+ $\left.], 5\right), 278$ (14), 264 (7), 246 (13), 220 (12), 188 (22), 169 (13), 154 (37), 135 (29), 122 (100); HR-EI-MS m/z [M] ${ }^{+}$(Calcd. for $\mathrm{C}_{16} \mathrm{H}_{24} \mathrm{O}_{5}$ 296.1624, Found 296.1623).

\subsection{Bioactivity Examination}

\subsubsection{Preparation of Human Neutrophils}

A study involving human neutrophils was approved by the Institutional Review Board at Chang Gung Memorial Hospital, Taoyuan, Taiwan, and was conducted according to the Declaration of 
Helsinki (2013). The written informed consent was obtained from each healthy donor before blood was drawn. Blood was drawn from healthy human donors (20-30 years old) by venipuncture into heparin-coated vacutainer tubes, using a protocol approved by the Institutional Review Board at Chang Gung Memorial Hospital. Blood samples were mixed gently with an equal volume of 3\% dextran solution. Neutrophils were isolated with a standard method of dextran sedimentation prior to centrifugation in a Ficoll Hypaque gradient and hypotonic lysis of erythrocytes. The leukocyte-rich plasma was collected after sedimentation of the red cells for $30 \mathrm{~min}$ at room temperature, and was transferred to $20 \mathrm{~mL}$ Ficoll solution $(1.08 \mathrm{~g} / \mathrm{mL})$ and spun down at $400 \mathrm{~g}$ for $40 \mathrm{~min}$ at $20{ }^{\circ} \mathrm{C}$. The granulocyte/erythrocyte pellets were resuspended in ice-cold $0.2 \% \mathrm{NaCl}$ to lyse erythrocytes [52]. After $30 \mathrm{~s}$, the same volume of $1.6 \% \mathrm{NaCl}$ solution was added to reconstitute the isotonic condition. Purified neutrophils were pelleted and then resuspended in a calcium $\left(\mathrm{Ca}^{2+}\right)$-free Hank's balanced salt solution (HBSS) buffer at $\mathrm{pH} 7.4$, and were maintained at $4{ }^{\circ} \mathrm{C}$ before use.

\subsubsection{Inhibition of Superoxide Anion Generation}

The assay of the generation of superoxide anion was based on the superoxide dismutase (SOD)-inhibitable reduction of ferricytochrome c [52,54]. In brief, after supplementation with $0.6 \mathrm{mg} / \mathrm{mL}$ ferricytochrome $\mathrm{c}$ and $1 \mathrm{mM} \mathrm{Ca}^{2+}$, neutrophils $\left(6 \times 10^{5}\right.$ cells $\left./ \mathrm{mL}\right)$ were equilibrated at $37^{\circ} \mathrm{C}$ for $2 \mathrm{~min}$ and incubated with drugs or an equal volume of vehicle $(0.1 \%$ DMSO, negative control) for $5 \mathrm{~min}$. Cells were activated with $100 \mathrm{nM}$ fMLP during the preincubation of $1 \mu \mathrm{g} / \mathrm{mL}$ cytochalasin B (fMLP/CB) for $3 \mathrm{~min}$. Changes in the absorbance with a reduction in ferricytochrome $\mathrm{c}$ at $550 \mathrm{~nm}$ were continuously monitored in a double-beam, six-cell positioner spectrophotometer with constant stirring (Hitachi U-3010). Calculations were based on differences in the reactions with and without SOD $(100 \mathrm{U} / \mathrm{mL})$ divided by the extinction coefficient for the reduction of ferricytochrome $\mathrm{c}$ ( $\varepsilon=21.1 / \mathrm{mM} / 10 \mathrm{~mm}$ at the concentration of $1 \mathrm{mM}$ in cuvette with 1 -cm optical path length).

\subsubsection{Inhibition of Elastase Release}

Elastase release was measured by degranulation of azurophilic granules as described previously [52,54]. Experiments were performed using MeO-Suc-Ala-Ala-Pro-Val-p-nitroanilide as the elastase substrate. Briefly, after supplementation with MeO-Suc-Ala-Ala-Pro-Val-p-nitroanilide $(100 \mu \mathrm{M})$, neutrophils $\left(6 \times 10^{5}\right.$ cells $\left./ \mathrm{mL}\right)$ were equilibrated at $37^{\circ} \mathrm{C}$ for $2 \mathrm{~min}$ and incubated with test compounds or an equal volume of vehicle $(0.1 \% \mathrm{DMSO}$, negative control) for $5 \mathrm{~min}$. Cells were activated by $100 \mathrm{nM}$ fMLP and $0.5 \mu \mathrm{g} / \mathrm{mL}$ cytochalasin $\mathrm{B}$, and changes in absorbance at $405 \mathrm{~nm}$ were continuously monitored to assay elastase release. The results were expressed as the percent of elastase release in the fMLP/CB-activated, drug-free control system.

\subsubsection{Statistical Analysis}

Normal distribution with Shapiro-Wilk was performed. The results are expressed as the mean \pm SD and analyzed by analysis of variance (ANOVA) with post-hoc Bonferroni multiple comparisons tests. Calculations of $50 \%$ inhibitory concentrations $\left(\mathrm{IC}_{50}\right)$ were computer-assisted (PHARM/PCS v.4.2). Statistical comparisons were made between groups using the Student's $t$ test. Values of $p$ less than 0.05 were considered to be statistically significant.

Supplementary Materials: ${ }^{1} \mathrm{H}-,{ }^{13} \mathrm{C}-\mathrm{NMR}$ and $2 \mathrm{D}$ spectroscopic data of $\mathbf{1}$ are available online.

Acknowledgments: This study is sponsored by the Ministry of Science and Technology, Taiwan, granted to T.-S.W. and Y.-Y.C. Authors are also thankful to Chang Gung Memorial Hospital (CMRPD1B0281 3, CMRPF1D0442 3, CMRPF 1F0011 3, CMRPF1F0061 3 and BMRP450 granted to T.-L.H.) for the partial financial support for the present research.

Author Contributions: Yu-Yi Chan and Ping-Chung Kuo performed the research and recorded the spectra. Tsong-Long Hwang had done the inhibition experiments on human neutrophils. Tian-Shung Wu designed the research and provided the research outlines. Yu-Yi Chan, Ping-Chung Kuo and Hsin-Yi Hung completed the manuscript draft. All authors read and approved the final manuscript. 
Conflicts of Interest: The authors declare no conflict of interest.

\section{References}

1. Chiu, N.Y.; Chang, K.H. The Illustrated Medicinal Plants of Taiwan, 1st ed.; SMC Publishing: Taipei, Taiwan, 1987; Volume III, p. 121.

2. Wang, Y.; Qian, J.; Cao, J.; Wang, D.; Liu, C.; Yang, R.; Li, X.; Sun, C. Antioxidant capacity, anticancer ability and flavonoids composition of 35 Citrus (Citrus reticulata Blanco) varieties. Molecules 2017, 22, 1114. [CrossRef] [PubMed]

3. Chan, Y.Y.; Wu, T.S.; Kuo, Y.H. Chemical constituents and cytotoxicity from the stem bark of Citrus medica. Heterocycles 2009, 78, 1309-1316.

4. Roohbakhsh, A.; Parhiz, H.; Soltani, F.; Rezaee, R.; Iranshahi, M. Molecular mechanisms behind the biological effects of hesperidin and hesperetin for the prevention of cancer and cardiovascular diseases. Life Sci. 2015, 124, 64-74. [CrossRef] [PubMed]

5. Murthy, K.N.; Jayaprakasha, G.K.; Patil, B.S. Cytotoxicity of obacunone and obacunone glucoside in human prostate cancer cells involves Akt-mediated programmed cell death. Toxicology 2015, 329, 88-97. [CrossRef] [PubMed]

6. Leclere, L.; Fransolet, M.; Cote, F.; Cambier, P.; Arnould, T.; Van Cutsem, P.; Michiels, C. Heat-modified Citrus pectin induces apoptosis-like cell death and autophagy in HepG2 and A549 cancer cells. PLoS ONE 2015, 10, e0115831. [CrossRef] [PubMed]

7. Zeng, Z.Y.; Chen, Y.; Zou, L.; Zhang, Y.; Hu, F.; Feng, J.; Shen, J.; Wei, B. Naringin inhibits growth and induces apoptosis by a mechanism dependent on reduced activation of NF- $\mathrm{KB} / \mathrm{COX}-2$ caspase-1 pathway in HeLa cervical cancer cells. Int. J. Oncol. 2014, 45, 1929-1936. [CrossRef] [PubMed]

8. Huber, R.; Stintzing, F.C.; Briemle, D.; Beckmann, C.; Meyer, U.; Gründemann, C. In vitro antiallergic effects of aqueous fermented preparations from Citrus and Cydonia fruits. Planta Med. 2012, 78, 334-340. [CrossRef] [PubMed]

9. Mokbel, M.S.; Hashinaga, F. Evaluation of the antioxidant activity of extracts from buntan (Citrus grandis Osbeck) fruit tissues. Food Chem. 2006, 94, 529-534. [CrossRef]

10. Tsai, H.L.; Chang, S.K.; Chang, S.J. Antioxidant content and free radical scavenging ability of fresh red pummelo [Citrus grandis (L.) Osbeck] juice and freeze-dried products. J. Agric. Food Chem. 2007, 55, 2867-2872. [CrossRef] [PubMed]

11. Kim, G.N.; Shin, J.G.; Jang, H.D. Antioxidant and antidiabetic activity of Dangyuja (Citrus grandis Osbeck) extract treated with Aspergillus saitoi. Food Chem. 2009, 117, 35-41. [CrossRef]

12. Parhiz, H.; Roohbakhsh, A.; Soltani, F.; Rezaee, R.; Iranshahi, M. Antioxidant and anti-inflammatory properties of the Citrus flavonoids hesperidin and hesperetin: An updated review of their molecular mechanisms and experimental models. Phytother. Res. 2015, 29, 323-331. [CrossRef] [PubMed]

13. Yu, H.Y.; Park, S.W.; Chung, I.M.; Jung, Y.S. Anti-platelet effects of yuzu extract and its component. Food Chem. Toxicol. 2011, 49, 3018-3024. [CrossRef] [PubMed]

14. Shende, S.; Ingle, A.P.; Gade, A.; Rai, M. Green synthesis of copper nanoparticles by Citrus medica Linn. (Idilimbu) juice and its antimicrobial activity. World J. Microbiol. Biotechnol. 2015, 31, 865-873. [CrossRef] [PubMed]

15. Chubukov, V.; Mingardon, F.; Schackwitz, W.; Baidoo, E.E.; Alonso-Gutierrez, J.; Hu, Q.; Lee, T.S.; Keasling, J.D.; Mukhopadhyay, A. Acute limonene toxicity in Escherichia coli is caused by limonene hydroperoxide and alleviated by a point mutation in alkyl hydroperoxidase AhpC. Appl. Environ. Microbiol. 2015, 81, 4690-4696. [CrossRef] [PubMed]

16. Wu, M.C.; Li, H.C.; Wu, P.H.; Huang, P.H.; Wang, Y.T. Assessment of oligogalacturonide from Citrus pectin as a potential antibacterial agent against foodborne pathogens. J. Food Sci. 2014, 79, 1541-1544. [CrossRef] [PubMed]

17. Vollmerhausen, T.L.; Ramos, N.L.; Dzung, D.T.; Brauner, A. Decoctions from Citrus reticulata Blanco seeds protect the uroepithelium against Escherichia coli invasion. J. Ethnopharmacol. 2013, 150, 770-774. [CrossRef] [PubMed]

18. Chan, Y.Y.; Li, C.H.; Shen, Y.C.; Wu, T.S. Anti-inflammatory principles from the stem and root barks of Citrus medica. Chem. Pharm. Bull. 2010, 58, 61-65. [CrossRef] [PubMed] 
19. La, V.D.; Zhao, L.; Epifano, F.; Genovese, S.; Grenier, D. Anti-inflammatory and wound healing potential of Citrus auraptene. J. Med. Food 2013, 16, 961-964. [CrossRef] [PubMed]

20. Impellizzeri, D.; Bruschetta, G.; Di Paola, R.; Ahmad, A.; Campolo, M.; Cuzzocrea, S.; Esposito, E.; Navarra, M. The anti-inflammatory and antioxidant effects of bergamot juice extract (BJe) in an experimental model of inflammatory bowel disease. Clin. Nutr. 2014, 33, 749-753. [CrossRef] [PubMed]

21. Mitoshi, M.; Kuriyama, I.; Nakayama, H.; Miyazato, H.; Sugimoto, K.; Kobayashi, Y.; Jippo, T.; Kuramochi, K.; Yoshida, H.; Mizushina, Y. Suppression of allergic and inflammatory responses by essential oils derived from herbal plants and Citrus fruits. Int. J. Mol. Med. 2014, 33, 1643-1651. [CrossRef] [PubMed]

22. Noh, H.J.; Hwang, D.; Lee, E.S.; Hyun, J.W.; Yi, P.H.; Kim, G.S.; Lee, S.E.; Pang, C.; Park, Y.J.; Chung, K.H.; et al. Anti-inflammatory activity of a new cyclic peptide, citrusin XI, isolated from the fruits of Citrus unshiu. J. Ethnopharmacol. 2015, 163, 106-112. [CrossRef] [PubMed]

23. Hattori, S.; Shimokoriyama, M.; Kanao, M. Studies on flavanone glycosides. IV. The glycosides of ripe fruit peel and flower petals of Citrus aurantium L. J. Am. Chem. Soc. 1952, 74, 3614-3615. [CrossRef]

24. Wu, T.S.; Kuoh, C.S.; Furukawa, H. Acridone alkaloids and a coumarin from Citrus grandis. Phytochemistry 1983, 22, 1493-1497.

25. McPhail, A.T.; Ju-ichi, M.; Fujitani, Y.; Inoue, M.; Wu, T.S.; Furukawa, H. Isolation and structures of citropone-A and -B from Citrus plants, first examples of naturally-occurring homoacridone alkaloids containing a tropone ring system. Tetrahedron Lett. 1985, 26, 3271-3272. [CrossRef]

26. Wu, T.S.; Huang, S.C.; Jong, T.T.; Lai, J.S.; Furukawa, H. Honyumine, a new linear pyranoacridone alkaloids from Citrus grandis Osbeck. Heterocycles 1986, 24, 41-43. [CrossRef]

27. Wu, T.S. Baiyumine-A and -B, two acridone alkaloids from Citrus grandis. Phytochemistry 1987, 26, 871-872. [CrossRef]

28. Wu, T.S.; Huang, S.C.; Jong, T.T.; Lai, J.S.; Kuoh, C.S. Coumarins, acridone alkaloids and a flavone from Citrus grandis. Phytochemistry 1988, 27, 585-587. [CrossRef]

29. Wu, T.S. Alkaloids and coumarins of Citrus grandis. Phytochemistry 1988, 27, 3717-3718. [CrossRef]

30. Huang, S.C.; Chen, M.T.; Wu, T.S. Alkaloids and coumarins from stem bark of Citrus grandis. Phytochemistry 1989, 28, 3574-3576. [CrossRef]

31. Wu, T.S.; Huang, S.C.; Lai, J.S. Stem bark coumarins of Citrus grandis. Phytochemistry 1994, 36, $217-219$.

32. Takemura, Y.; Ju-ichi, M.; Ito, C.; Furukawa, H.; Tokuda, H. Studies on the inhibitory effects of some acridone alkaloids on Epstein-Barr virus activation. Planta Med. 1995, 61, 366-368. [CrossRef] [PubMed]

33. Marıín, F.R.; Martinez, M.; Uribesalgo, T.; Castillo, S.; Frutos, M.J. Changes in nutraceutical composition of lemon juices according to different industrial extraction systems. Food Chem. 2002, 78, 319-324. [CrossRef]

34. Giuffrè, A.M.; Zappia, C.; Capocasale, M. Physico-chemical stability of blood orange juice during frozen storage. Int. J. Food Prop. 2017, in press.

35. Harkar, S.; Razdan, T.K.; Waight, E.S. Steroids, chromone and coumarins from Angelica officinalis. Phytochemistry 1984, 23, 419-426. [CrossRef]

36. Wu, T.S.; Chang, F.C.; Wu, P.L.; Kuoh, C.S.; Chen, I.S. Constituents of Leaves of Tetradium Glabrifolium. J. Chin. Chem. Soc. 1995, 42, 929-934. [CrossRef]

37. Sendker, J.; Böker, I.; Lengers, I.; Brandt, S.; Jose, J.; Stark, T.; Hofmann, T.; Fink, C.; Abdel-Aziz, H.; Hensel, A. Phytochemical characterization of low molecular weight constituents from marshmallow roots (Althaea officinalis) and inhibiting effects of the aqueous extract on human hyaluronidase-1. J. Nat. Prod. 2017, 80, 290-297. [CrossRef] [PubMed]

38. He, H.Y.; Ling, L.; Zhou, M. Isolation and structure elucidation of two dimeric limettins from fingered citron. Youji Huaxue 1987, 3, 193-196.

39. Sugimoto, T.; Miyase, T.; Kuroyanagi, M.; Ueno, A. Limonoids and quinolone alkaloids from Evodia rutaecarpa bentham. Chem. Pharm. Bull. 1988, 36, 4453-4461. [CrossRef]

40. Aquino, R.; Cáceres, A.; Morelli, S.; Rastrelli, L. An extract of Tagetes lucida and its phenolic constituents as antioxidants. J. Nat. Prod. 2002, 65, 1773-1776. [CrossRef] [PubMed]

41. Chan, Y.Y.; Juang, S.H.; Huang, G.J.; Liao, Y.R.; Chen, Y.F.; Wu, C.C.; Chang, H.T.; Wu, T.S. The Constituents of Michelia compressa var. formosana and their bioactivities. Int. J. Mol. Sci. 2014, 15, 10926-10935. [CrossRef] [PubMed] 
42. Boyd, D.R.; Sharma, N.D.; Harrison, J.S.; Malone, J.F.; McRoberts, W.C.; Hamilton, J.T.G.; Harper, D.B. Enzyme-catalysed synthesis and reactions of benzene oxide/oxepine derivatives of methyl benzoates. Org. Biomol. Chem. 2008, 6, 1251-1259. [CrossRef] [PubMed]

43. Huang, C.H.; Chan, Y.Y.; Kuo, P.C.; Chen, Y.F.; Chang, R.J.; Chen, I.S.; Wu, S.J.; Wu, T.S. The constituents of roots and stems of Illigera luzonensis and their anti-platelet aggregation effects. Int. J. Mol. Sci. 2014, 15, 13424-13436. [CrossRef] [PubMed]

44. Claydon, N.; Frederick, J.; Pople, G.M. Elm bark beetle boring and feeding deterrents from Phomopsis oblonga. Phytochemistry 1985, 24, 937-943. [CrossRef]

45. Steevesa, V.; Försterb, H.; Pommerb, U.; Savidgea, R. Coniferyl alcohol metabolism in conifers-I. Glucosidic turnover of cinnamyl aldehydes by UDPG: Coniferyl alcohol glucosyltransferase from pine cambium. Phytochemistry 2001, 57, 1085-1093. [CrossRef]

46. Marco, J.A.; Sanz-Cervera, J.F.; Sancenon, F.; Jakupovic, J.; Rustaiyant, A.; Mohamadit, F. Oplopanone derivatives monoterpene glycosides from Artemisia sieberi. Phytochemistry 1993, 34, 1061-1067. [CrossRef]

47. Chan, Y.Y.; Leu, Y.L.; Wu, T.S. The constituents of the leaves of Aristolochia heterophylla Hemsl. Chem. Pharm. Bull. 1999, 47, 887-889. [CrossRef]

48. Gattuso, G.; Barreca, D.; Caristi, C.; Gargiulli, C.; Leuzzi, U. Distribution of flavonoids and furocoumarins in juices from cultivars of Citrus bergamia Risso. J. Agric. Food Chem. 2007, 55, 9921-9927. [CrossRef] [PubMed]

49. Yuan, Y.; Win Aung, K.K.; Ran, X.K.; Wang, X.T.; Dou, D.Q.; Dong, F. A new sesquiterpene lactone from yacon leaves. Nat. Prod. Res. 2017, 31, 43-49. [CrossRef] [PubMed]

50. Yang, S.; Wang, L.; Guo, X.J.; Lou, H.X.; Ren, D.G. A new flavonoid glycoside and other constituents from Dracocephalum moldavica. Nat. Prod. Res. 2013, 27, 201-207. [CrossRef] [PubMed]

51. Sakai, K.; Takahashi, K.; Nukano, T. Convenient synthesis of optically active abscisic acid and xanthoxin. Tetrahedron 1992, 48, 8229-8238. [CrossRef]

52. Yang, S.C.; Chung, P.J.; Ho, C.M.; Kuo, C.Y.; Hung, M.F.; Huang, Y.T.; Chang, W.Y.; Chang, Y.W.; Chan, K.H.; Hwang, T.L. Propofol inhibits superoxide production, elastase release, and chemotaxis in formyl peptide-activated human neutrophils by blocking formyl peptide receptor 1. J. Immunol. 2013, 190, 6511-6519. [CrossRef] [PubMed]

53. Yu, H.P.; Hsieh, P.W.; Chang, Y.J.; Chung, P.J.; Kuo, L.M.; Hwang, T.L. 2-(2-Fluorobenzamido) benzoate ethyl ester (EFB-1) inhibits superoxide production by human neutrophils and attenuates hemorrhagic shock-induced organ dysfunction in rats. Free Radic. Biol. Med. 2011, 50, 1737-1748. [CrossRef] [PubMed]

54. Strehmel, N.; Böttcher, C.; Schmidt, S.; Scheel, D. Profiling of secondary metabolites in root exudates of Arabidopsis thaliana. Phytochemistry 2014, 108, 35-46. [CrossRef] [PubMed]

Sample Availability: Samples of the purified compounds are available from the authors.

(C) 2017 by the authors. Licensee MDPI, Basel, Switzerland. This article is an open access article distributed under the terms and conditions of the Creative Commons Attribution (CC BY) license (http:/ / creativecommons.org/licenses/by/4.0/). 